\title{
FREEDOM OF EXPRESSION: THE CONTINUING REVOLUTION
}

\author{
LAWRENCE W. BEER*
}

I

\section{INTRODUCTION}

In August 1989, at his first press conference, Emperor Akihito defended the democratic right of individuals to comment on and criticize the imperial institution or a particular emperor, even his father, Hirohito. ${ }^{1}$ In so doing, the Emperor reaffirmed the constitutional revolution on behalf of freedom of expression and other human rights that began in the autumn of 1945 , and encouraged uninhibited public discourse on politically sensitive subjects. By soft-spoken implication, he attacked the rightists making death threats against Mayor Hitoshi Motoshima of Nagasaki, a critic of Emperor Hirohito's role in the Second World War. ${ }^{2}$ One might look in vain through the sixty-two years of the Showwa Period for a similar instance of unequivocal imperial advocacy of free speech and an open society. ${ }^{3}$ Rather, without reference to the personal views of Hirohito, conservative revisionists and extreme rightists may have depended on the expressive silence of the imperial household as implicit approval of their efforts since the 1950 s to restore the emperor to greater constitutional prominence and to discourage open discourse on the imperial institution and in general. ${ }^{4}$ Both silence and expression reveal the status of freedom of expression in a country, and that freedom is a critical test of constitutional democracy. The other side of an orthodoxy is its attendant taboos-topics on which silence is enforced or powerfully encouraged-such as the emperor system in Japan and socialism in the United States.

For over four decades, the prewar orthodoxy of emperor-centered, repressive nationalism seems to have contended among political elites with

Copyright $(1990$ by Law and Contemporary Problems

* F.M. Kirby Professor of Civil Rights, Lafayette College; Visiting Scholar, University of Washington Law School, 1989-1990.

1. Reuters News Service, Aug. 4, 1989.

2. Mayor Motoshima was seriously wounded by an ultranationalist on January 18, 1990. Sanger, Mayor Who Faulted Hirohito Is Shot, New York Times, Jan. 19, 1990, at A6, col. 4.

3. Japanese count years according to the Christian Era, but also from the first year of the incumbent emperor's reign. Hirohito's era, the Bright Peace (Shōwa) Period, began in 1926; after death, an emperor is referred to by the era name rather than his personal name, hence Emperor Shöwa. Emperor Akihito's reign is referred to as Achieving Peace (Heisei).

4. See N. Hōshakaigakkai, Tennosei No Hōshakaigakuteki Kosatsu (1978); D. Titus, Palace and Politics in Prewar Japan (1974); Higuchi, Sato \& Beer, Japan (1947): Forty Years of the Post-War Constitution, in Constitutions in Democratic Politics 173-205 (V. Bogdanor ed. 1988) (on the revisionist controversy); Okudaira, Forty Years of the Constitution and its Various Influences: Japanese, American, and European, LaW \& Contemp. Pross., Winter 1990, at 17 (on the tenno modern emperor system). 
the orthodoxy of the 1947 Constitution, which is characterized by popular sovereignty, quasi-pacifist internationalism, freedom of expression, and other human rights. Much of Japan's Liberal Democratic Party leadership during this period seems to have found it hard to reconcile the earlier nationalistic orthodoxy in which they were educated with the revolutionary orthodoxy of freedom, which insists on tolerating diverse, even contradictory, views on basic public values and other issues. ${ }^{5}$

The passing of Emperor Hirohito on January 7, 1989, seems part of a major transition from the postwar generation of leaders to a new generation educated in the past half century. This generational succession is part of a broad pattern of leadership changes in Asia during the 1980s. The emerging leaders of Japan are more apt to be matter-of-fact than passionate about the emperor and Shinto, more comfortable than some of their predecessors with the 1947 Constitution, and increasingly confident about Japan's prominence among nations, if not about its precise implications. ${ }^{6}$ At this juncture of generational leadership succession, the revolution of freedom may be as firmly institutionalized in Japan as in virtually any other constitutional democracy.

Why freedom of expression is relatively strong in Japan or any country cannot be ascertained simply by looking at laws, constitutional provisions, and judicial decisions. The reasons and reality are most effectively unearthed by empirically well-founded, ecological analysis of factors such as social culture, institutions of government and law, economic conditions, political value commitments, and historical serendipity. Free speech is nowhere permanently established and uniformly or fully enjoyed. Opinion research suggests that while a majority in the United States, for example, supports freedom of expression in the abstract, a majority also opposes much free speech for those espousing views quite different from their own. ${ }^{7}$ Other survey research indicates that in Japan college-educated adults now express more confidence in the 1947 Constitution than in any other national institution. ${ }^{8}$ Freedom of expression on a particular topic at a given time exists in a constitutional culture in part because of widespread trust in the system and a national consensus that the inherent equal dignity of each person requires protection of each individual's freedom in law and politics. Freedom of expression also exists because the balance of competitive sociopolitical forces favors expression rather than repressed silence on the subject, at least for the moment. The test of freedom is whether, in general, a citizen actually has the option of expressing himself peacefully or remaining silent about a subject without negative social, legal, or economic consequences. These

5. Higuchi, Sato \& Beer, supra note 4.

6. See L. Beer, Constitutionalism in Asia: Asian Views of the American Influence iii-xi (1988) (on leadership succession in Asia).

7. Gibson \& Bingham, On the Conceptualization and Measurement of Political Tolerance, 76 AM. PoL. Scr. Rev. 603 (1982); Powell, American Voter Tumout in Comparative Perspective, 80 Am. Pol. Scr. Rev. 35 (1986).

8. J. Marshall, Japan's Successor Generation: Their Values and atritudes (1985). 
perspectives are useful for examining Japan's record. After setting forth relevant constitutional provisions and touching lightly on the institutional and social context of freedom of expression in Japan, this essay surveys judicial holdings on freedom of assembly and association, the expression rights of workers, and the freedom of the mass media.

\section{II}

\section{Constitutional Provisions on Freedom}

Social culture affects law, and widely accepted legal norms and institutions affect the status of freedom of expression in society. The 1947 Constitution sets forth the broad array of rights guaranteed to Japanese citizens. ${ }^{9}$ In general terms, Article 11 guarantees "the fundamental human rights" as "eternal and inviolable rights," while Article 97 refers to these rights as "conferred upon this and future generations in trust, to be held for all time inviolate."

Article 21 is the primary provision affecting freedom of expression: "Freedom of assembly and association as well as speech, press and all other forms of expression are guaranteed. No censorship shall be maintained, nor shall the secrecy of any means of communication be violated."

Article 15 establishes the people's "inalienable right to choose their public officials and to dismiss them," implying rights of election campaigning. ${ }^{10}$ Article 16 guarantees the right of peaceful petition and forbids discrimination against a petitioner for opposing or advocating a particular official action. The 1947 Petition Law ${ }^{11}$ implementing this provision has seldom been invoked in a free speech case, but organized citizen demands on government are commonplace. Freedom of religious expression and the right not to "be compelled to take part in any religious acts, celebration, rite or service" are established in Article 20.12 With Article 23, Japan's constitution was the first to guarantee academic freedom. Workers have the right "to organize and to bargain and act collectively" under Article 28. Under Article 51, Diet members cannot be held liable outside parliament "for speeches, debates or votes cast inside." Significantly, Article 82 requires that "trials of political

9. See especially 1947 Const. arts. 11-40 (ch. 3). For the full text of the 1947 Constitution, see Appendix, LaW \& Contemp. Probs., Spring 1990. 133.

10. See Usaki, Restrictions on Political Campaigns in Japan, LAw \& Contemp. Probs., Spring 1990, at

11. Petition Law, Law No. 13, 1947. For a translation of this law, see L. BeER, Freedom of Expression in Japan: A Study in Comparative Law, Politics and Society 193-94 n.9 (1984). Article 16 of the Constitution provides:

Every person shall have the right of peaceful petition for the redress of damage, for the removal of public officials, and for the enactment, repeal or amendment of laws, ordinances, or regulations or other matters, nor shall any person be in any way discriminated against for sponsoring such a petition.

12. Other provisions also affect the freedom of religious expression and the separation of religion and the state. Article 19 guarantees "freedom of thought and conscience," and Article 89 prohibits the use of public resources for a religion or for any nonprofit institution "not under the control of public authority." 
offenses involving the press or cases wherein the rights of people guaranteed in Chapter $3 \ldots$ are in question shall always be conducted publicly." 13

Counterbalancing individual rights in the Constitution is "the public welfare" (kōkyō no fukushi), a phrase found in Articles 12 and 13:

Article 12. The freedoms and rights guaranteed to the people by this Constitution shall be maintained by the constant endeavour of the people, who shall refrain from any abuse of these freedoms and rights, and shall always be responsible for utilizing them for the public welfare.

Article 13. All of the people shall be respected as individuals. Their rights to life, liberty, and the pursuit of happiness shall, to the extent that it does not interfere with the public welfare, be the supreme consideration in legislation and in other governmental affairs.

Officials and constitutional lawyers have long debated how, if at all, courts and other government agencies should use the public welfare clause in decisions affecting freedom of expression and other rights. Definitions of the phrase have ranged from abstract references to public order, the collective good, or state policy, to specific criteria related to one category of court cases. For example, provisions for parade regulation are designed to serve the public interest of smooth traffic flow. In general terms, a 1950 Supreme Court statement reflects the spirit of self-disciplined liberty in the Constitution: "[T]he maintenance of order and respect for the fundamental human rights-it is precisely these things which constitute the content of the public welfare."14 The courts use the clause as a positive law standard, not merely as a hortatory statement of an ideal. Judicial interpretation of the above constitutional provisions and other law relevant to freedom of expression will be introduced with the case law below.

\section{III}

\section{Society, Government, and Freedom}

In Japan, judges and prosecutors play roles of great importance to the ecology of free speech. ${ }^{15}$ Leaders in other establishment systems serve important functions as well. For decades, educators from primary school through the university have effectively indoctrinated students into believing democratic principles are part of the Japanese way. In addition, the overwhelming majority of constitutional lawyers and other legal professionals continually reaffirm the legitimacy of freedom of expression. Artists of many categories and the mass media confidently assume their expression rights, as do private associations of all sizes throughout the country. And in their competitive political discourse and internal rules, most of Japan's diverse

19. Article 82 allows other types of cases to "be conducted privately if a court unanimously determines publicity to be dangerous to public order or morals."

14. Japan v. Sugino, 4 Keishū 2012, 2014 (Sup. Ct., G.B., 1950). See also L. Beer, supra note 11, at 151-52 (on the public welfare). The public welfare also qualifies specific rights to property (Article 29) and to choice of residence and occupation (Article 22).

15. See Itoh, Judicial Review and Judicial Activism in Japan, LAw \& Contemp. Probs., Winte: 1990, at 169; Kamata, Adjudication and the Governing Process: Political Questions and Legislative Discretion, LAw \& Contemp. Probs., Winter 1990, at 181 . 
political parties take for granted and generally confirm by practice the law of freedom.

The year 1989 was especially rich in free political discourse, with its controversial new tax and imperial ceremonies, with the Recruit Cosmos Company exposé and Cabinet-level sex scandals, and with the defeat of the ruling party in parliamentary elections for the upper house. ${ }^{16}$ But does the ordinary citizen enjoy the right to freedom of expression in everyday life? The answer to this question often depends more on society than on government and law. Social values and behavior patterns specific to each culture affect both the degree and the characteristics of free expression in a country's sociopolitical life. ${ }^{17}$ In Japan, for example, homogeneity, group orientation, social hierarchy (oyabun-kobun), quasi-parental-filial relationships, reciprocal dependency patterns (amae), and ethnic separatism join the civil law, common law, and conciliation traditions to affect freedom and restraint of expression.

Japan is a nonindividualist, group-centered society in which vigorous expression of diverse views emanates from very cohesive groups rather than from isolated individuals. The individual's self-realization is assumed to occur within rather than apart from his or her primary group. Powerless individuals anywhere are less effective defenders than are well-organized groups of both free speech in general and specific interests. Thus, "groupism" may be more supportive of democratic freedom under law than is individualism. Two test points for the individual's freedom of expression in Japan's group-structured society, where the ideal of consensus rather than majority rule governs, are: (1) whether an individual in-group member is allowed free expression of views at the preconsensus stage of group decisionmaking or consensus formation on an issue, and is not sanctioned after consensus is reached for having earlier advocated a contrary position, and (2) whether a competitiveminded group excessively presses its own interests in complete disregard of the rights of other groups, individuals, or the public-an "individualistic groupism" that is analogous to the extreme individualism shown by one who is blind to others' rights in an individual-oriented society such as the United States. ${ }^{18}$

Japanese culture values individual reticence and, in many contexts, views aggressive assertion of personal opinion as reprehensible; therefore, Japan's system of freedom of expression requires modalities of dispute resolution and politics that encourage citizens to assert their rights under law freely. Conciliation by a third party is often preferred to adjudication in a court of

16. See Asahi Shimbun and The Japan Times, July 1988 to Sept. 1989 for coverage.

17. L. BEER, supra note 11 , at 100-28. The precise impact of a cultural attribute on freedom in a given case is a matter for subtle interpretation of empirical data; the problems are well discussed in Ramseyer \& Nakazato, The Rational Litigant: Settlement Amounts and Verdict Rates in Japan, $18 \mathrm{~J}$. Legal STud. 263 (1989). See also Gaenslen, Culture and Decisionmaking in China, Japan, Russia, and the United States, 39 WORLD Pol. 78 (1986) (comparative study).

18. For an extended analysis of the relevance to freedom of expression of Japan's orientation towards the group and duty rather than the individual and rights, see L. BEER, supra note 11 , at 396 . 
law. ${ }^{19}$ Officially sanctioned mediation of disputes, both public and private, is well established. Welfare Commissioners (Min'ei Iin), neighborhood police, family courts, and other agencies assist parties in reconciling differences without resort to complex, expensive, and time-consuming legal processes, and without loss in the quality of justice. ${ }^{20}$

As elsewhere, individuals, more than groups, need free speech law that encourages, not merely allows, the expression of concerns. In the ecology of freedom in Japan, two distinctive examples of systems that encourage the assertion of citizen rights at the sidewalk-and-rice-roots level are the Jinken Yogo Iin and the Local Administrative Counselors (Gyōsei Sodan Iin). ${ }^{21}$ Probably for historical reasons, ${ }^{22}$ the government has translated Jinken Yogo Iin as "Civil Liberties Commissioner"; however, that term is inaccurate and misleading. Jinken Yogo Iin literally means "Human Rights Protector"; and "human rights" encompass far more under Japan's law than "civil liberties."23 Perhaps Jinkin Yogo may be best rendered as "Human Rights Commissioner." These local commissioners, meticulously selected for their human rights credentials, serve for renewable three-year terms. Their duties include consultation by individuals regarding human rights problems, human rights education, conciliatory settlement of neighborhood disputes, and referral of serious rights violations to the appropriate authorities. They are typically very approachable, non-elitist, respected men and women.

Local Administrative Counselors, like the Human Rights Commissioners, are unpaid volunteers. They average sixty years of age and work for renewable two-year terms under the Bureau of Administrative Inspection of the Administrative Management Agency (AMA). ${ }^{24}$ The AMA began entertaining thousands of citizen complaints a year against government offices around 1955, more as a means of improving the quality of administration than as a technique of human rights enforcement. Amendments to the 1948 AMA Law in 1960 and 1961 first empowered the AMA to use Local Administrative Counselors to resolve complaints against government agencies. In the 1980s, about 5,000 of these respected counselors were dealing on an impartial and

19. This preference does not mean that Japanese disputants settle for less than they would receive as a result of a trial. See Ramseyer \& Nakazato, supra note 17 . Mediation and arbitration are widely used in the United States; binding arbitration is not used in Japan. On American practice, see Galanter, Reading the Landscape of Disputes: What We Know and Don't Know (and Think We Know) about Our Allegedly Contentious and Litigious Society, 31 UCLA L. REv. 4 (1983), and the publications of the National Institute for Dispute Resolution, Washington, D.C., which analyze American approaches to dispute resolution.

20. For further examples of lay participation, see L. BEER, supra note 11, at 140-44.

21. L. Beer, Human Rights Commissioners (Jinken Yogo Jin) and Lay Protection of Human Rights in Japan (Occasional paper No. 31, Int'l Ombudsman Inst. 1985).

22. Historically, the institution was inspired by discussions during the Occupation between Japanese and American officials about the new civil rights section of the criminal division of the United States Department of Justice (now the Civil Rights Division) and about civil liberties, the primary American emphasis in the human rights area.

23. Human Rights Commissioner Law, Law No. 139, 1949.

24. See L. BEER, supra note 11 , at 142.43 (on local administrative counselors); Beer \& Weeramantry, Human Rights in Japan: Some Protections and Problems, 1 Universal Hum. RTs. 14 (1979) (on problems dealt with by volunteers); L. Beer, supra note 21. 
confidential basis with roughly 200,000 complaints each year against public officials.

The Human Rights Commissioners and Local Administrative Counselors play a small but significant part in a complex sociolegal system generally favoring freedom of expression. They are useful, well institutionalized, and worthy of emulation; their task would be even more impressive if the Human Rights Bureau received more adequate funding. They serve as examples of well-focused, officially supported, and socially supported voluntarism that transcends narrow interests and government bureaucratism, costs little, and brings relief to millions of citizens suffering from ostracism, discrimination, official arrogance, environmental disruption, cruel treatment due to age or illness, and other afflictions to which the flesh is heir.

\section{IV}

\section{Some Judicial Decisions on Freedom of Assembly and Association}

The competitiveness and nonindividualism of Japan's sociopolitics seem to make the freedoms of assembly and association particularly critical to the infrastructure of the nation's constitutional democracy. Both freedoms were effectively suppressed, especially during the wartime period of 1930 to 1945. ${ }^{25}$ Now, demonstrations and campaigns of protest regarding tax and trade issues, environmental pollution, airport expansion, working conditions, and other problems enliven national discourse, irrepressibly reaffirm freedom to act, and only rarely degenerate into violence. ${ }^{26}$

Since 1948, the content or application of Public Safety Ordinances (kōan jōrei) has been at issue in much of the litigation involving freedom of assembly. ${ }^{27}$ Sixty such city and prefectural ordinances establish local public safety commissions (kōan iinkai) composed of three to five locally respected citizens; fifty-three ordinances require a permit, and the remaining ordinances require prior notification. Denial of a permit almost never occurs, but conditions have often been attached regarding the time, place, and manner of a public gathering, parade, or demonstration under both permit and notification systems. The reasonableness of restraints attendant to such conditions or the prima facie constitutionality of ordinance provisions has been disputed in a series of court cases. In addition, Article 77 of the Road Traffic Law (Dōro Kōtsuhō) ${ }^{28}$ authorizes local public safety commissions to require a police permit for parades and demonstrations in the interest of orderly traffic flow (as around construction sites), and the Criminal Code

25. L. Beer, supra note 11 , at 45-72; R. Mitchell, Censorship in IMPERIal. Japan (1983); R. Mitchell, Thought Control in Prewar Japan (1976).

26. See, e.g., McKean, Equality, in Democracy in Japan 201 (T. Ishida \& E. Krauss eds. 1989) (hereinafter Democracy); Steinhoff, Protest and Democracy, in Democracy 171; Turner, Democratic Consciousness in Japanese Unions, in Democracy 299.

27. See L. BEER, supra note 11, at 16I-204.

28. Road Traffic Law, Law No. 105, 1960; see also L. BeER, supra note 11, at 166. 
covers various types of group violence, such as riots, insurrections, and obstruction of the performance of police duties. ${ }^{29}$

Perhaps the most important judicial decision on freedom of assembly is the 1960 Grand Bench judgment of the Supreme Court in the Tokyo Ordinance case. ${ }^{30}$ Under the ordinance, group representatives apply to the police for a permit. If the police deny permission or attach conditions (for example, changing the route or time of a demonstration), they must justify their decision to the Tokyo Public Safety Commission for final disposition. However, many groups have held demonstrations without applying for a permit, particularly during the late 1940 s and the 1950 s.

The particular historical backdrop to the Tokyo Ordinance case is as follows. In 1959 and 1960, Japan's "consensual democracy" was powerfully confirmed during the Security Treaty crisis by the largest mass movement in the nation's history. Millions were involved for months in passionate but usually nonviolent political demonstrations in Tokyo and other cities; only one life was lost, and that by accident. Whether or not Japan should cast her lot indefinitely with the United States was much debated; but more central to the maelstrom may have been the allegedly undemocratic arrogance of Prime Minister Nobusuke Kishi and the ruling Liberal Democratic Party (LDP), who were "ramming through" the revised U.S.-Japan Treaty of Mutual Cooperation and Security ${ }^{31}$ with their parliamentary majority. Apparently, premature reliance on the majority vote without giving adequate hearing to all views, and thus possibly achieving a partial consensus, deprived the decision of unquestioned legitimacy.

In related 1959 cases, Tokyo district courts refused to allow police to detain students demonstrating without a permit, but the government won a reversal in mid-1960 on direct appeal to the Supreme Court. In an extended opinion affecting subsequent judicial reasoning, the Court held that a freedom such as freedom of assembly "is the most important feature that distinguishes democracy from totalitarianism," and that the courts are required under law "to draw a proper boundary between freedom and the public welfare." 32 The potential for violence in collective activities such as demonstrations justifies public safety ordinances to establish "the minimum measures necessary to maintain law and order." 33 The Tokyo Ordinance is constitutional because it requires the Public Safety Commission to issue a permit unless a proposed demonstration would "directly endanger the

29. See L. BEER, supra note 11 , at 166-68.

30. Ito v. Japan, 14 Keishú 1243 (Sup. Ct., G.B., July 20, 1960). For the text of the Tokyo Ordinance and a translation of the decision, see J. Maki, Court and Constitution In Japan 84-1 16 (1964).

31. Treaty of Mutual Cooperation and Security, Jan. 19, 1960, United States-Japan, 11 U.S.T 1632, T.I.A.S No. 4509. See also Japan v. Sakane, 23 Keishū 685 (Sup. Ct., G.B., Apr. 2, 1969) (decision on an incident arising during the Security Treaty crisis). For the texts of the treaty and the Sakane opinion, see H. Itoh \& L. Beer, The Constitutional Case Law of Japan 103-30 (1978).

32. See J. MAKI, supra note 30 , at 88 .

33. Id. at 89 . 
maintenance of the public peace." 34 It is "profitless," the court said, to debate whether the ordinance's regulation of gatherings "in any place whatsoever" is unconstitutionally broad. ${ }^{35}$ Nor does the ordinance create "a general prohibition" on demonstrations by not allowing them when officials fail to act on an application by the scheduled time of the event. ${ }^{36}$

The Tokyo Ordinance decision continues to be a powerful precedent, but subsequent lower and appellate court holdings have refined procedural standards and made more concrete the guidelines for applying the ordinance to the place and circumstance of a collective activity. Since the mid-1960s, many lower court judges have taken a more relaxed view of the dangers posed by crowds. ${ }^{37}$ In the 1975 Tokushima Ordinance case, ${ }^{38}$ the Supreme Court seemed more positive in its assessment of political demonstrations. In that case, Manabu Teramae, a union official and antiwar activist, was convicted under the Road Traffic Law and the Tokushima Public Safety Ordinance for a 1964 demonstration against visiting U.S. nuclear submarines, for leading a snake dance down city streets in a 1968 protest against the presence of B-52 bombers in Japan, and for attendant violence. The district court held Article 3 of the ordinance unconstitutionally vague in requiring demonstration leaders to "maintain orderly traffic." The majority in the highest tribunal reversed on the grounds that "a person of ordinary common sense" would be able to apply Article 3 to "a concrete case," but some Justices acknowledged a deficiency in the Article's wording.

A 1977 decision of Judge Shoji Terao of the Tokyo High Court, ${ }^{39}$ confirmed by the Supreme Court in 1979, was less ambiguous in its appreciation of demonstrations and labor union campaigns than the Tokyo Ordinance case, the Tokushima Ordinance case, and many other appellate holdings. In a decision handed down sixteen years after the demonstrations and eleven years after trial, Judge Terao upheld convictions for illegal demonstrations, but reduced the sentences from imprisonment to mild fines. He wondered in his reasoning about the constitutionality of prior restraint under the Tokyo Ordinance, and pointedly criticized those who exaggerate the dangers inherent in democratic collective activities.

The Narita Airport case, ${ }^{40}$ decided in 1986 , involved a rare instance of substantial violence and provides further illustration of a pattern of delayed justice in politically sensitive cases. Tortuously long trials are the exception in Japan's criminal justice system. In the occasional political case, delays sometimes occur. A protracted trial may be intended by defense attorneys using the court as a forum, or it may be a natural, unintended effect of civil

34. Id.

35. Id. at 90 .

36. Id.

37. See L. BEER, supra note 11 , at 183-85.

38. Japan v. Teramae, 29 Keishū 489 (Sup. Ct., G.B., Sept. 10, 1975).

39. Kato v. Japan, 854 Hanrei Jihō 52 (Tokyo H. Ct., June 7, 1977). See also L. BeEr, supra note 11 , at 187 .

40. Asahi Shimbun (evening ed.), Oct. 4, 1986; The Japan Times, Oct. 19, 1986, at 2, col. 1. 
law judicial process in which a trial takes place in a number of court sessions strung out over a considerable period of time. The prospect of an interminable trial may dampen enthusiasm for collective activities more than some other legal and administrative restraints. In a 1971 clash, some 260 Mobile Police (Kidotai) confronted 700 opponents of government land acquisition for the Narita International Airport near Tokyo. Three police officers were killed, and many on both sides were injured. (Typically, the effective Mobile Police outnumber protesters, and injuries are few.) Not until October 1986 did the Chiba District Court issue its decision, giving fifty-two protestors suspended sentences (ten months to three years in duration) and acquitting three, in part because their confessions were inadmissible as evidence. The prosecution did not appeal, for lack of further evidence.

Freedom of association is routinely enjoyed in Japan. Alexis de Tocqueville's point about America 150 years ago might be made of Japan today (admittedly, without adequate comparative data in either case): "In no country in the world has the principle of association been more successfully used or applied to a greater multitude of objects . .."41 Among the laws enabling and regulating associations, certain provisions of the Subversive Activities Prevention Law (Hakaikatsudō Bōshihō) of 1952 have been challenged. ${ }^{42}$ The law has not often been invoked in constitutional litigation because terrorist acts are quite rare in Japan and because the constitutionality of the law is questioned by lawyers. Mindful of the prewar thought-control system, legislators who supported the law were opposed to controlling ideas, but thought it necessary to regulate the terrorist actions of antidemocratic organizations. Early in the Occupation (1945-52), extreme rightist groups were the primary concern; with the advent of the Cold War and instances of communist violence between 1947 and 1952, leftist organizations were targeted for restraint, as in prewar Japan. At present, terrorist acts by extremists are of minor concern.

Prior restraints on collective activities, violent group actions, and too harsh or excessively lenient sentences for related crimes do not negatively affect the enjoyment of freedom in Japan. Rather, overreliance on confessions at the preindictment stage, excessive detention without bail or adequate legal representation, and needlessly long trials in political cases affect the quality of the system regulating the freedoms of assembly and association. These restraints have not inhibited the strong drive to group self-expression through demonstrations, factional in-fighting, intergroup intolerance, and a multitude of autonomous associations. Groupism seems to reinforce rather than weaken the individual's rights to associate with likeminded people in minicommunities and to participate in the vigorous expression of collective views.

41. A. De Toceueville, Democracy in America 191 (P. Bradley ed. 1945).

42. Subversive Activities Prevention Law, Law No. 240, 1952. See also L. BeER, supra note 11 , at 188-93. 


\section{EXPRESSION RightS OF EMPLOYEES}

Union workers in Japan enjoy constitutional rights "to organize and to bargain and act collectively," in addition to the freedoms of collective activity they enjoy as citizens. ${ }^{43}$ Some of these protections do not extend to many public employees (kōmuin). ${ }^{44}$ Under Article 7 of the Labor Relations Adjustment Law, ${ }^{45}$ private sector unions may engage in "dispute activities" (sōgi kōi) such as "strikes, slowdowns, lock-outs, and other acts and counteractions carried out by parties in labor relations to achieve their objectives, which obstruct the normal conduct of business." "Other acts" are union actions interfering with business operations in order to activate the law's dispute settlement procedures. ${ }^{46}$ Acts are "proper" and immune from legal sanctions if they are nonviolent and are undertaken for economic rather than political gains. The Supreme Court has tended "to regard only the collective refusal to work as a proper act of dispute." 47 However, the Labor Union Law, which covers over 70 percent of union members, clearly recognizes the propriety of "other acts" in Articles 1, 7, and 8, and unions make use of a colorful array of obstructive activities during labor disputes. ${ }^{48}$

For decades, the denial to civil servants of both freedom of political expression, except through the ballot box, and worker rights to engage in collective bargaining or dispute activities has engendered bitter controversy. ${ }^{49}$ In general, and especially since 1973, Supreme Court decisions have upheld the constitutionality of restrictive laws such as the National Public Employees Law (NPEL), the Public Enterprise Labor Relations Law (PELRL), and the Rules (kisoku) of the National Personnel Authority (NPA) (Jinjiin). Typically, the Justices have comprehensively denied expression rights to public workers by relying on constitutional provisions with respect to the public welfare, the concept of "the collective benefit of all the people," and the need for political neutrality lest citizen trust be lost. During the latter half of the 1960s, however, the Supreme Court stressed worker rights in its statutory interpretation and, where alternative sanctions were available, imposed a lenient administrative reprimand rather than, for example, a harsh one-year suspension from employment. ${ }^{50}$

43. 1947 Const. arts. 28, 21.

44. See L. BEer, supra note 11, at 215-39 (on the relevant labor law).

45. Law No. $25,1946$.

46. Id. arts. 6, 12.

47. T. Hanami, Labour Law and Industrial Relations in Japan 182 (1979); L. Beer, supra note 11 , at 216; see also id. at 222.

48. See L. BEER, supra note 11, at 216-19 (for numerous examples of union tactics).

49. Id. at 220-39. For a chart of restrictive legal provisions, see id. at 224. The general legal basis for restraints are Article 102 of the National Public Employees Law, Law No. 120, 1947, and Article 26 of the Local Public Employees Law, Law No. 261, 1950. The prohibited political acts are left to prescription in detail in the Rules of the National Personnel Authority.

50. Toyama v. Japan (The Tokyo Central Post Office Case), 20 Keishū 901 (Sup. Ct., G.B., Oct. 26, 1966); L. BEeR, supra note 11, at 232-35. For a translation of this case, see H. ITOH \& L. BeER, supra note 31. at 85-130. 
In its 1966 Tokyo Central Post Office decision, ${ }^{51}$ the Supreme Court required the high court to reconsider whether postal union leaders' incitement of workers to leave work and hold a rally during the 1958 "spring labor offensive" was "justifiable." The Court upheld the constitutionality of Article 17 of the PELRL, which forbids such incitement, but gave the court below interpretive guidelines, for instance: "[T]he fundamental rights of workers engaging in public services or in public enterprises involve restrictions different from that of private enterprise only according to the nature of their duties." 52 The majority maintained that distinctions should be made between types of work, between legitimate labor dispute acts and political activities, between degrees of illegality and public inconvenience caused, and between mild sanctions and criminal penalties that would be disproportionate for failure to perform a contractual obligation.

With the 1973 All-Japan Agriculture and Forestry Workers Union (Zennōrin) case, ${ }^{53}$ the Supreme Court shifted decisively to a more restrictive policy based on literal interpretation of the statutes, acceptance of the authority of NPA Rules, and rejection of all distinctions among public employees based on the nature of their work. In 1958, Zennorin, other unions, and opposition political parties successfully opposed a revision of the Police Duties Law, which they feared might lead to repression of the labor movement, as in prewar Japan. A union leader issued a call for some 3,000 members to hold a two-hour political rally during work hours, and other political activities were organized. The union leaders were convicted for "political strike" activities, illegal for both public and private workers. Like all litigants in subsequent cases, the union leaders unsuccessfully challenged the NPEL and other laws as violating constitutional provisions governing workers' rights, expression rights, and/or procedural rights.

In the famous 1974 Sarufutsu case, ${ }^{54}$ the Supreme Court reversed an acquittal and convicted a postal worker for putting up six political posters on a public bulletin board during leisure hours. The majority reasoned, first, that public officials must be politically neutral in order to retain public trust in their impartiality. Second, although the law does not intend restraints on expression of opinion, that may be an inevitable side effect. Third, the Court rejected the view of lower court decisions that administrative sanctions should be seen as "less restrictive means" or preferable to criminal penalties. Four dissenting justices argued that criminal penalties, as contrasted with administrative punishment, are constitutional only when the political acts of public employees cause grave and direct harm, or the danger of such harm, to

51. 20 Keishū 901 ; see H. Itoh \& L. Beer, supra noce 31 , at 85 for translation.

52. See H. IтоH \& L. BeER, supra note 31 , at 91 for translation.

53. Tsuruzono v. Japan (The All-Japan Agriculture and Forestry Workers Union Case), 27 Keishū 547 (Sup. Ct., G.B., Apr. 25, 1973). For an explanation of Supreme Court decisions in this case, the Tokyo Central Post Office case, and other cases involving public employees, see L. BEER, supra note 11 , at 234-36.

54. Japan v. Osawa, 28 Keishū 393 (Sup. Ct., G.B., Nov. 6, 1974) (reversing 514 Hanrei Jihō 20 (Asahikawa Dist. Ct., Mar. 25, 1968) and 560 Hanrei Jihō 30 (Sapporo H. Ct., June 24, 1969)). 
the state or to social interests. Neither threat was present in this case. This view has been supported by many constitutional lawyers. ${ }^{55}$ Unfortunately, the controlling judicial doctrine has been that public workers may be criminally liable even if their acts do not impair performance of duty and are performed away from official premises, by off-duty, nonmanagerial employees, in a peaceful manner. ${ }^{56}$

For many years, the National Personnel Authority (NPA) has punished thousands of public employee union members for illegal dispute activities or political acts. Most NPA disciplinary actions have consisted of a reprimand, but many have also included a pay cut or temporary "suspension from duty." A few have resulted in firings. ${ }^{57}$ Other government bodies also mete out penalties short of criminal prosecution to activist employees.

Occasionally, members of public employee unions mount a successful challenge in court. For example, on December 18, 1986, the Supreme Court upheld a lower court order quashing a reprimand issued by the Hokkaido Education Commission against five high school teachers. ${ }^{58}$ These union members had used half of an annual school holiday in 1965 to participate in a rally with colleagues from other schools. The gathering was part of labor's annual springtime "joint struggle." When the teachers notified the principal of their intention three days beforehand, he and the education commission forbade their attendance as a. dispute activity violating the Local Public Employees Law. ${ }^{59}$ The Supreme Court denied that such use of a holiday amounted to a strike, since it did not interfere with classes and other schools had allowed the activity. The officials' felt need to litigate to reassert control over innocent activities is more noteworthy and typical than the Supreme Court's vindication of the teachers.

In 1989, a historic unification of most public and private sector unions under one umbrella organization took place. The Japanese Private Sector Trade Union Confederation (Rengō) established local chapters in forty-seven prefectures in March. In November it joined with the General Council of Trade Unions (Sōhyō) to form the ten-million-member Japanese Trade Union Confederation (Shin Rengo). ${ }^{60}$ At this writing, it was not clear what effect this

55. See L. BEER, supra note 11 , at ch. 6, and Japanese sources cited therein.

56. Id. at 231-39.

57. Id. at $225-30$.

58. Hokkaido Education Commission v. Hayashi, Asahi Shimbun, Dec. 19, 1986 (Sup. Ct., 1st P.B., Dec. 19, 1986).

59. See Articles 37 and 61 of the Local Public Employees Law, supra note 49, as translated in $\mathbf{H}$. ITOH \& L. BEER, supra note 31 , at 86-87.

60. The Japanese Private Union Confederation, JPTUC-Rengo, was founded on November 20, 1987, under Toshifumi Tateyama with the goal of unifying labor. On its successful plans to confederate with public sector unions, see JPTUC, The Direction and Role of Rengo (1988), and the monthly RenGo, from December 1987 to present. Perhaps the major split occasioned by the unification was that between the Japanese Teachers Union (Nikkyoso) and the 28,000 member Tokyo Teachers Union, which called for a rival national union supportive of the Japan Communist Party. 28 JAPAN LAB. Bull. 3 (1989) (figures entitled "Trends in Labor Disputes by Type of Dispute" and "Trends in Labor Disputes Accompanied by Dispute Actions, Number of Employees Involved and Working Days Lost"); Japan Times, Oct. 6, 1989. 
consolidation of labor forces might have on patterns of worker rights' assertion and regulation, and whether related opposition parties such as the Japan Socialist Party and Kōmeitō would coalesce to challenge successfully the perennially governing LDP.

\section{VI}

\section{Mass Media Rights and Responsibilities}

Due in part to the vigor, freedom, and power of the mass media, a wide range of issues affecting their rights and responsibilities has been raised in social debate and in the courts. Freedom lives and is moderated in the interplay of formal law, politics, and social culture in daily life; so the discussion that follows, however briefly, mixes context with court holdings. After a few comments on obscenity, a more detailed sketch is presented of rights regarding freedom of information, secrecy, media privileges, and textbook publishing problems.

Japanese society is rather tolerant of erotica in print, in pictures, and in other media. ${ }^{61}$ Regulatory authority is spread among many public and private agencies. Since 1907, Article 175 of the Criminal Code has punished lightly the distribution and sale of obscene matter. ${ }^{62}$ Since 1910, under Article 21 of the Customs Standards Law, the Customs Bureau has censored imported "written material and pictures harmful to public order and public morals," 63 a system of disputed constitutionality. The Supreme Court has held that obscene passages in a book infect the whole and that a judgment on obscenity should be made with respect for the public welfare according to "prevailing social ideas" or "the common sense of society," without too much attention to a work's artistic or social values. ${ }^{64}$ In a mid-1980s poll, 80 percent of Japanese adults (up 19 percent since 1980) said they felt that mass-media portrayals of sex-particularly in weekly magazines, television, and filmswere excessively explicit. Of these 80 percent, 73.3 percent preferred that minors under eighteen not be exposed to these portrayals. Close to 90 percent of all respondents complained of the public sale of pornography in

61. See generally L. BEER, supra note 11, at 335-61.

62. Article 175 provides that:

A person who distributes or sells an obscene writing, picture, or other object or who publicly displays the same, shall be punished with imprisonment at forced labor for not more than two years or a fine of not more than 5,000 yen or a minor fine. The same applies to a person who possesses the same for the purpose of sale.

Keihō (Penal Code), Art. 175 (as translated from Ministry of Justice, Criminal Statutes I 39 (1961)).

63. Customs Standards Law, Law No. 54, 1910 (as amended 1980).

64. Matsue v. Japan, 38 Minshú 1308 (Sup. Ct., G.B., Dec. 12, 1984). See L. BEer, supra note 11, at 347-55 (on obscenity decisions of the Supreme Court); Ishii v. Japan, 23 Keishū 1239 (Sup. Ct., G.B., Oct. 15, 1969) (translated in H. IтоH \& L. BEER, supra note 31, at 183-217); Koyama v. Japan, 11 Keishū 997 (Sup. Ct., G.B., Mar, 13, 1957) (translated in J. Makı, supra note 30, at 3-37). The works at issue were Japanese translations of D.H. Lawrence's Lady Chatterley's Lover, and de Sade's The Travels of Juliette. 
vending machines. ${ }^{65}$ To this writer, permitting private adult access to virtually any media material seems the best general guideline; nonetheless, in order to protect minors' development rights (however "minor" is defined chronologically in a given culture), moderate restraint on obscene, excessively violent, or otherwise degrading material seems reasonable.

\section{A. Defamation, Privacy, and Press Freedom}

The rights to reputation and privacy have been balanced against press freedom under Articles 709 and 710 of the Civil Code, which require compensation for intentional or negligent violation of another's right. ${ }^{66}$ No distinction is made between libel and slander; defamation (meiyo kison) is prohibited under both Article 723 of the Civil Code and Articles 230 and 2302 of the Criminal Code. Damage awards and fines have been moderate or small. A published apology is also required in some cases. ${ }^{67}$ Supreme Court interpretations in the late 1960s moved away from punishing the simple public allegation of facts (whether true or false) as defamation. This interpretation had resulted from a literal reading of the codes. The Supreme Court has moved to a doctrine in both criminal and civil cases under which one escapes liability for an otherwise defamatory comment when the allegations, even if factually mistaken, concern a matter of public interest, were made for public benefit, and were published in a belief that they were true, based on what the court considers sufficiently objective evidence. ${ }^{68}$ Two cases decided in the 1980 s illustrate debated issues.

65. Japan Times Weekly, Dec. 14, 1985. This pattern of concerns is consistent with other poll data since the late 1970s.

66. Article 710 provides that "[a] person who is liable [under art. 709] shall make compensation therefore even in respect of a non-pecuniary damage, irrespective of whether such injury was to the person, liberty or reputation of another or to his property rights." Minpō (Civil Code), art. 710.

67. Article 723 provides that "[i]f a person has injured the reputation of another, the Court may, on the application of the latter, make an order requiring the former to take suitable measures for the restoration of the latter's reputation either in lieu of or together with compensation for damages." Id. art. 723.

68. The Criminal Code of Japan provides:

Article 230. A person who defames another by publicly alleging facts shall, regardless of whether such facts are true or false, be punished with imprisonment at or without forced labor for not more than three years or a fine of not more than 1,000 yen . . .

Article 230-2. When the act provided for [in Article 230] . . . is found to relate to matters of Public Interest [(kōkyō no rigai)] and to have been done solely [(moppara)] for the benefit of the public and, upon inquiry into the truth or falsity of the alleged facts, the truth is proved, punishment shall not be imposed ....

Article 230-3. When the act provided for [in Article 230] . . is done with regard to matters concerning a public servant or a candidate for elective public office and, upon inquiry into the truth or falsity of the alleged facts, the truth is proved, punishment shall not be imposed. Keırō, art. 230. For judicial doctrine on defamation, see Kochi v. Japan, 23 Keishū 259 (Sup. Ct., G.B., June 25, 1969) (translated in H. IтоH \& L. BeER, supra note 31, at 175); see also L. BeER, supra note 11, at 318-25. In a much-discussed political case, in which the Japan Communist Party demanded that the Sankei Shimbun newspaper publish its unpaid advertisement responding to the Liberal Democratic Party's paid advertisement attacking the Japan Communist Party in December 1973, the Supreme Court denied a constitutional right to refutation under Article 21 . Japan Communist Party v. Sankei Shimbun, Asahi Shimbun, Apr. 25, 1987, at 1 (Sup. Ct., 2d P.B., Apr. 24, 1987). 
In 1976, the monthly magazine Gekkan Pen published Articles critical of Soka Gakkai, the lay Buddhist organization, and its leader, the well-known public figure Daisaku Ikeda. In 1981, the Supreme Court ${ }^{69}$ overturned the lower court's finding of defamation. The Court held that Ikeda's affairs were not private, but rather matters of public interest calling into play Article 2302. The highest tribunal noted the public importance of Soka Gakkai and the social influence of Ikeda as a public figure, and directed the lower courts to reexamine the facts objectively. The Tokyo courts then convicted the accused on a finding that the truth of the magazine's allegations was not proved, and that the accused lacked sufficient grounds for believing them true. ${ }^{70}$

The rather intricate Hoppó Jonaru (The Northern Journal) case involved a provisional injunction against publishing an issue of a magazine without giving its representatives a hearing. ${ }^{71}$ The April 1979 issue was to carry an Article harshly critical of Kozo Igarashi, a well-known Socialist member of parliament and former mayor of Asahikawa City who was about to run for Governor of Hokkaido, Japan's large northern island. The Supreme Court ${ }^{72}$ approved this use of an injunction to prevent defamation against the claim of Takao Ona of the journal that it was illegal prior restraint and censorship, violating Article 21 of the Constitution. The Court argued that, in general, a hearing was procedurally required and that prior restraint was improper, but that in this instance the Article, "A Power Seeker's Temptations," was so extreme in its insults, vulgarity, and personal attack as obviously to lack credibility on a first reading. The injunction did not constitute censorship in the meaning of Article 21 because it was a judicial act, not the result of an administrative process. As a rare exception, the Court held that a provisional injunction was appropriate because the Article's contents were untrue, the Article was not written solely for public benefit, and Igarashi's reputation would have suffered severe and probably irreparable damage if it had been published. The Article was a lively blend of political and strictly personal comment on Igarashi. To the Court, character assassination trumped the public-interest value of comment on a candidate for public office. Would its publication have affected the election's outcome? If it was so extreme, would not quick rebuttal have been relatively easy? To anyone familiar with the effect of the Willie Horton advertisement on U.S. television during the 1988 presidential campaign and the powerful effectiveness of negative campaigning, the answers are not obvious or simple.

The right of privacy (puraibashii no kenri) was first recognized in Japanese law in a 1964 Tokyo District Court decision involving Yukio Mishima's After the Banquet (Utage no ato), ${ }^{73}$ a "model novel" mixing fact and fiction in its

69. Gekkan Pen v. Japan, 35 Keishū 34 (Sup. Ct., 1st P.B., Apr. 16, 1981).

70. 1128 Hanrei Jihō 32 (Tokyo H. Ct., July 18, 1984).

71. See L. BEER, supra note 11, at 324-25; Aoyanagi, Meiyo Kison Hyogen No Shihöteki Jizen Kösei, 77 Hōgaku Kyōshitsu Bessatsu 15 (1987).

72. Ona v. Igarashi, 40 Minshū 872 (Sup. Ct., G.B., June 11, 1986). See also Asahi Shimbun (evening ed.), Oct. 2, 1981 , at 1 .

73. Y. Mishima, AFter the Banquet (D. Keene trans. 1963). 
depiction of the marital affairs of Hachiro Arita, a noted Tokyo politician. Mishima had received Mrs. Arita's consent, but not Mr. Arita's, before serializing the story in a major magazine $(C h \bar{u} \bar{o}$ Köron $) .{ }^{74}$ The names of the principals were disguised by pseudonyms, but upon reading the novel, both Aritas were outraged, and Mishima was successfully sued for what became the largest damage award until then (approximately $\$ 2,220$ in U.S. currency).

The court defined the right of privacy as "the legal right and assurance that one's private life will not be wantonly opened to the public," applying it to both individual and family life and basing it on the Constitution's Article 13 requirement that "[a]ll of the people shall be respected as individuals."75 A privacy right is violated when: (1) fear exists that a work may be taken as factual or close to the facts of one's personal life; (2) the average person would not want the matters publicized; and (3) the work presents material that is generally unknown. ${ }^{76}$ Four considerations, on balance, may negate illegality: (1) artistry; (2) freedom of expression; (3) the public position of the aggrieved party; and (4) the prior consent of the party. ${ }^{77}$ Mishima lost, but the court denied the Aritas' request that a published apology be required on grounds that in a privacy case, in contrast to an instance of defamation, restoration of the status quo ante is impossible. A right to one's own image (shōzōken) has been discussed in and out of court as a type of privacy right. ${ }^{78}$ The inventively snoopy photo magazines have continued to enrage or humiliate entertainers and other public figures over the decades; but the will to regulate seems weak, and the felt right to know strong, in this area. ${ }^{79}$

\section{B. Mass Media Freedoms and Information Rights}

The mass media industry in Japan is free, organizationally strong, selfregulating, ${ }^{80}$ technically sophisticated, and diverse. It is about as informative, entertaining, and educational as any nation's system. The national newspapers and television news programs enjoy much more public trustparticularly among the college-educated-than any sector of government except the Supreme Court. ${ }^{81}$ Sustained investigative newspaper, magazine, and television reporting on sensitive matters has been infrequent, as in other

74. L. BEER, supra note 11 , at 325-30.

75. Arita v. Mishima, 15 Kakminshū 2317 (Tokyo Dist. Ct., Sept. 28, 1964).

76. Id.

77. Id. See also L. BEER, supra note 11 , at 326.

78. Hasegawa v. Japan, 23 Keishũ 1625 (Sup. Ct., G.B., Dec. 24, 1969) (translated in H. Iтон \& L. BEER, supra note 31 , at 178). A right to likeness as a privacy right was unsuccessfully claimed in a case challenging the constitutionality of a system automatically taking photos of speeders. $40 \mathrm{Keishu}$ 48 (Sup. Ct., 2d P.B., Feb. 14, 1986). See also Japan Times, Jan. 12, 1987, at 2, col. 6.

79. See Japan Times, supra note 78 (on efforts to curb media intrusions on privacy); L. BEER, supra note 11, at 316-19. The attack on Kodansha magazines by television personalities Kokku Yokoyama and Biito Takeshi in 1986 symbolized the resentment of entertainers at media intrusiveness. Asahi Shimbun, Dec. 16-17, 1986; Japan Times, Dec. 17, 1986, at 2, col. 5.

80. See L. BEER, supra note 11 , at 283 , 285-89, 316-18, 338-46 (on various self-regulatory systems of the mass media).

81. J. Marshall, supra note 8 . 
democracies. ${ }^{82}$ On the other hand, the national newspapers, such as the Asahi Shinbun, Yomiuri Shinbun, Mainichi Shinbun, and Nihon Keizai Shinbun, have been major actors in political and policy debates at a few critical junctures, for example, during the Security Treaty crisis in $1960,{ }^{83}$ the diffusion of the antipollution consensus in 1970,84 and the exposure of the Recruit Cosmos stock scandal in 1988 and $1989 .{ }^{85}$

\section{VII}

\section{Secrecy and Press Freedom}

Some parameters of press freedom have been clarified by appellate court decisions in the Hakata Station Film case in 1969,86 the Nishiyama State Secrets case in $1978,{ }^{87}$ and the Hokkaido Newsman's Privilege case in $1980 .^{88}$ In $\mathrm{Hakata}^{89}$ four television stations in southwest Japan refused to comply with a court order to present (teishutsu meirei) for use as criminal evidence film they had taken in 1968 during a train station clash between students and police. The students were on their way home from demonstrations in southern Japan protesting a visit of the aircraft carrier U.S.S. Enterprise. The television companies, backed by the Japan Newspaper Editors and Publishers Association (Nihon Shinbun Kyōkai), and virtually the entire mass media industry, argued that "the use of this film as court evidence might render free and impartial newsgathering and reporting impossible." The Grand Bench unanimously disagreed, but confirmed that Article 21 of the Constitution guarantees the freedom to gather news and to report facts and ideas in service of the public's right to know, and that freedom of information is at the foundation of democracy. Since the film in question had already been used in news broadcasts, the Court said, its purpose was achieved; so the court order did not directly affect newsgathering freedom. The Court reasoned that although the use of the film for another purpose might lead someone not to cooperate with reporters sometime in the future, hypothetical harm must be balanced against the need for evidence to assure a fair trial. Other sources of

82. See L. BEE, supra note 11, at 281-89. For coverage of related problems in the American mass media, see generally the publications of the Gannett Center for Media Studies, Columbia University, New York, particularly the Gannett Center Joumal and Communique.

83. See supra note 31 and accompanying text.

84. See Beer, Japan Turning the Corner, 11 Asian Surv. 74 (1971).

85. The Recruit scandal emerged in 1988. Japanese prosecutors contend that the information services and real estate corporate conglomerate Recruit Company and a subsidiary bought influence in government by giving cash and discounted stock to top political figures in the ruling Liberal Democratic Party, high ranking government bureaucrats, and prominent businessmen. See Ex-Recruit Chief Questioned Over Objective in Share Deals, The Japan Times Weekly Overseas Edition, Jan. 4, 1989, at 2. See also Samuels, Japan in 1989: Changing Times, 30 Asian Survey 46 (1990).

86. Kaneko v. Japan, 23 Keishū 1490 (Sup. Ct., G.B., Nov. 26, 1969) (translated in H. IтоH \& L. BEER, supra note 31, at 246). See also L. BEER, supra note 11, at 294-97.

87. Nishiyama v. Japan, 32 Keishū 457 (Sup. Ct., 1st P.B., May 31, 1978); L. BeEr, supra note 11 , at 303-05.

88. Sasaki v. Japan, 930 Hanrei Jihō 44 (Sapporo Dist. Ct., Mar. 30, 1979)

89. 23 Keishū 1490 . 
evidence had proved inadequate, the Justices continued, and the film was virtually indispensable to a determination of guilt or innocence.

The television stations subsequently refused to obey the Supreme Court. In the absence of other alternatives, a seizure order was issued by the district court and the film was used as evidence. In 1970, the district court upheld the students' contention that police had abused their authority, but dismissed their case on grounds that, even with the videotapes, the identities of the individual police officers involved were not clear. In this struggle between the courts, the media, and the police, the responsible police officials did not cooperate with the courts and were not disciplined by higher authority for keeping secret the names of the guilty police officers.

Japan has no freedom of information statute, but in the $1980 \mathrm{~s}$ a national movement for greater openness in the bureaucratized government has resulted in approximately 140 local ordinances on information control. ${ }^{90}$ Conversely, no law forbids spying or otherwise adequately protects state secrets. The state secrets bills proposed repeatedly by the ruling party in the mid-1980s met strong and successful opposition, ${ }^{91}$ in part perhaps because they manifested little sensitivity to citizen rights such as freedom of information. Some law is necessary to deal with security problems attendant to the worldwide transfer of commercial technology, whether the technology be military or civilian in nature. This was illustrated in recent years by the Soviet Union's purchase of state-of-the-art milling machines for submarine propellers from a Norwegian company and a division of Japan's Toshiba. ${ }^{92}$ The citizen's right to know is more essential to democracy than international commercial freedom and should be given more serious consideration in debates on what legal limits on freedom are the minimum necessary. But how to balance freedom of information with legitimate national security concerns and how to distinguish in law the narrowly political secret from a state secret are difficult questions.

The Supreme Court first ruled on state secrets and a reporter's newsgathering rights in the 1978 Nishiyama case. ${ }^{93}$ Takichi Nishiyama, a Mainichi political reporter, violated a solemn promise to his source, Kikuko Hasumi, a Foreign Ministry employee, in leaking sensitive information she had provided to an opposition member of the Diet. In 1971, Nishiyama induced Hasumi, his lover, to give him the contents of secret cables sent during the U.S.-Japan negotiations for the 1972 reversion of Okinawa to Japanese sovereignty. Shortly after the exchange of ratification documents

90. For example, a law providing limited personal control over data concerning oneself was developed in the 1980s. L. BEER, supra note 11, at 305-06.

91. A number of "state secrets bills" (Kokka himitsu hoan) formulated by LDP leaders were vigorously attacked and eventually withdrawn or allowed to die in committee. See generally Asahi Shimbun, 1986-1988.

92. The Toshiba companies went so far as to publish a full-page apology advertisement in the New York Times, more noticed perhaps in Japan than in the United States. Asahi Shimbun, July 20, 1987.

93. 32 Keishū 457. 
but before reversion, the parliamentarian revealed that, contrary to government assurances that no secret agreements had been made, Japan had secretly agreed to pay $\$ 5$ million to Okinawans in land-damage claims. Prime Minister Eisaku Sato took "deep responsibility" for the incident but did not admit any improper suppression of information. Nishiyama and Hasumi (both married) were soon exposed, arrested, and convicted of violating the National Public Employees Law. Article 100(1) prohibits revealing secrets learned while carrying out official duties. Nishiyama was charged with inducing a civil servant to commit a crime. The maximum sentence for secrecy violations-hypothetically including those seriously harmful to Japan and/or other nations-is only one year in prison and a small fine.

Nishiyama appealed on grounds of press freedom. The Supreme Court, in rejecting his appeal, held that: (1) the courts have the authority to determine what is a state secret under the NPEL and what is a legally unprotected political secret; (2) the government's secrecy during the negotiations on Okinawa was appropriate; (3) the government's failure to bring the facts before the Diet did not violate the constitutional order or constitute illegal secrecy; and (4) while free newsgathering and reporting are critical to the people's right to know and to freedom of expression, Nishiyama's ethically questionable relations with Hasumi involved illegal inducement. The Supreme Court's questionable legitimation of unnecessary and patently political secrecy and official lying to the parliament and public was matched by Nishiyama's violation of both family ethics and the professional ethics of a journalist. Though adultery was not the issue in the case, the Court seemed to take more note of Nishiyama's violation of family ethics than of professional ethics. "Overlooked in the later uproar about the relationship between Nishiyama and Hasumi was that Nishiyama's employer, the Mainichi Shinbun, chose to remain silent about a controversial issue of public importance despite its own brave words about a 'people's right to know.' "94

What if Hasumi had brought forth the story of government deception on her own, as a conscientious whistleblower? In the Hakata case, suppose an informed police officer had exposed his guilty colleagues. Or imagine the early intervention of a responsible public or private employee to reveal the Recruit Cosmos scandal ${ }^{95}$ or, in the United States, the "Iran-Contra" fiasco or the 1989 scandals in the Department of Housing and Urban Development. It is not clear that such whistleblowing would result in reward or neutral acceptance rather than punishment. In addition to ordinary mechanisms to assure accountability (for example, the Administrative Management Agency), encouragement in law for concerned but vulnerable employees is needed. Public disclosure of executive wrongdoing will be rare indeed in a system relying on the heroism of subordinates. In Japan, as elsewhere, a formidable future challenge to the freedoms of expression and information is the

94. Brown, Government Secrecy and the "People's Right to Know" in Japan: Implications of the Nishiyama Case, 10 LAW IN JAPAN 112,138 (1977).

95. See supra note 85 . 
development of effective legal protections for employees in both the public and private sectors who are willing to expose illegal activities at their places of work. One possible support for such responsible citizenship may be legal recognition of a "newsman's privilege" not to divulge confidential sources.

A newsman's privilege (shögen kyozetsuken-literally, the right to refuse to testify) - was first recognized in a 1979 civil case by the Sapporo District Court, ${ }^{96}$ but the issue has been debated for decades. In 1949, Kiyoshi Ishii of the Asahi newspaper published an Article about the impending arrest of a local tax official before the police had made it public. At the official's trial, Ishii, with the strong support of his employer and the Publishers Association, refused to be sworn to testify regarding the name of his source. In 1952, the Supreme Court ${ }^{97}$ denied his claim that a reporter's communications with a confidential source are "privileged," as are certain other professional confidences under Article 105 of the Code of Criminal Procedure.98 Withholding this prerogative does not violate free press guarantees under Article 21. Rather, the Court said, such a newsman's privilege could obstruct criminal justice and lead to improper favoritism in the treatment of reporters and other writers.

On the other hand, the Sapporo District Court, sustained by the appellate courts, ${ }^{99}$ held that Article 281 of the Code of Civil Procedure ${ }^{100}$ protects a newsman's privilege as a witness to refuse to divulge information on a source as "an occupational secret" (shokugyō no himitsu) unless it blocks access to evidence necessary for a fair trial. In an Article for the Hokkaido Shinbun in June 1977, Hideshige Shimada alleged that parents were complaining about child abuse in Masako Sasaki's nursery. Sasaki sued Shimada and his newspaper for erroneous and defamatory reporting, and asked for payment of damages and publication of an apology. Under questioning, Shimada declined to identify his sources. The courts upheld his privilege on grounds that, when a fair trial is not at issue, revealing confidential sources would improperly impair a reporter's pursuit of his pæofession.

96. 960 Hanrei Jihō 44.

97. Ishii v. Japan, 6 Keishū 974 (Sup. Ct., G.B., Aug. 6, 1952) (translated in J. MAKI, supra note 30 , at 38 ).

98. Articles 105 and 149 of the Code of Criminal Procedure establish as privileged professional confidences those of "a person who is, or was, a doctor, dentist, midwife, nurse, practicing attorney, patent agent, notary public or a religious functionary." Keihō (Code of Criminal Procedure) arts. $105,149$.

99. 30 Minshū 403 (Sapporo H. Ct., Aug. 31, 1979); see also Asahi Shimbun (evening ed.), Mar. 8, 1980 (Sup. Ct., 3d P.B., Mar. 8, 1980).

100. Article 281 of the Code of Civil Procedure provides:

A witness may refuse to testify in the following cases: ... In a case where a doctor, dentist, pharmacist, druggist, midwife, lawyer, patent attorney, advocate, notary public or an occupant of a post connected with religion or worship or a person who was once in such profession is questioned regarding [professional secrets].

Minsohō (Code of Civil Procedure) art. 281 (translated in EHS L. Bull. Series, Vol.III, No. 2300, LA-54 (1963)). 
VIII

\section{Courtroom Note-Taking and Reporters Clubs}

In 1989, the Supreme Court ${ }^{101}$ again granted a special prerogative to the news media by holding that the equality requirements of Article 14 of the Constitution are not violated when judges allow only news reporters to take notes in court during a trial. The judicial policy was not persuasively grounded in Article 21 or in Article 82's provision for public trials. ${ }^{102}$ Since the 1960s, however, Japan's courts had generally denied permission to take notes in the courtroom to all but members of the "reporters club" (kisha kurabu-commonly, but inaccurately translated as "press club") attached to the courts. Judges have "courtroom police powers" (hotei keisatsuken) under Article 71 of the Court Organization Law, but no strong contempt or subpoena powers (as illustrated by the Hakata case). ${ }^{103}$ The restrictive policy on note-taking may have arisen in reaction to courtroom disruptions during politically charged trials in earlier postwar decades. ${ }^{104}$

The courts' policy was challenged in 1985 by an American lawyer conducting research in Tokyo under a Japan Foundation Fellowship. Lawrence Repeta of Seattle began attending trial sessions in Tokyo District Court in October 1982 as part of his research project. Like other judges in Japan, the presiding judge prohibited note-taking in court as a general policy. Before each session, Repeta asked the judge's permission to take notes and

101. Repeta v. Japan, 43 Minshū 89 (Sup. Ct., G.B., Mar. 8, 1989) (reversing 1222 Hanrei Jihō 28 (Tokyo Dist. Ct., Feb. 12, 1987) and 1262 Hanrei Jihō 30 (Tokyo H. Ct., Dec. 25, 1987)); Asahi Shimbun, Mar. 9, 1989, at 2; 936 JuRishuto $17-44$ (June 15, 1989).

102. The 1947 Constitution states:

Article 82. Trials shall be conducted and judgment declared publicly. Where a court unanimously determines publicity to be dangerous to public order or morals, a trial may be conducted privately, but trials of political offenses, offenses involving the press or cases wherein the rights of people as guaranteed in Chapter III of this Constitution are in question shall always be conducted publicly.

1947 Const. art. 82.

Another issue affecting research on trials is the difficulty of gaining access to court trial records, although Article 53(1) of the Code of Criminal Procedure provides that "any person may examine the court record after the conclusion of a criminal case." See Shōko, Saiban Kiroku was Dare no Mono $\mathrm{Ka}$, Shorun: Bunger Shunju Opinion Magazine, July 1989, at 121-29.

103. Article 71 provides:

The presiding judge or a single judge who has opened a court shall maintain order in the court.

The presiding judge or a judge who has opened a court may order any person who interferes with the exercise of functions of the court or who behaves himself improperly, to leave the court, and may issue such other orders or take such measures as are necessary for the maintenance of order in the court.

Court Organization Law, Law No. 59, 1947 (translated in EHS L. Bull. SERIEs, vol. II-AA, 23 (1966)).

104. For example, the restrictive policy may have arisen in reaction to trials arising from mass political activity during May Day observances in 1952, during the Security Treaty crisis in 1960, and during the University crisis in 1969. Beer, Japan, 1969: "My Homeism" and Political Struggle, 10 Asian SuRv. 43 (1970). 
was denied. However, the judge did allow note-taking by reporters belonging to the local judicial press club.

Repeta sued the government, claiming that the judge's denial of permission violated a trial spectator's right to know under Articles 14, 21, and 82. He also cited Article 19 on freedom of expression in both the United Nations Universal Declaration of Human Rights and the International Covenant on Civil and Political Rights. ${ }^{105}$ Repeta argued that a citizen's right to information about government is fundamental to democracy and that a right to take notes in court or in any public place (in abbreviated form, "memoken," a "memo right") is implied by the right of anyone to attend a trial under Article 82. Moreover, the gathering and communication of information are essential to the enjoyment of freedom of expression and the right to know. "In reality," he maintained, "if people do not take notes, they cannot fully understand trials nor transmit knowledge concerning trials." One might substitute the word "lectures" for Repeta's "trials" and draw a parallel with a college student's need for lecture notes to pass a course.

The Tokyo District Court and High Court disagreed with Repeta's position, emphasizing the authority of a judge to decide whether a particular activity in a courtroom would in some way interfere with an orderly and fair trial. ${ }^{106}$ Although trials are generally open to the public, the individual does not have a right to attend a particular public trial. On March 8, 1989, the Grand Bench, in a complex opinion, ${ }^{107}$ unanimously upheld judicial prerogatives and refused to recognize a new constitutionally protected right to observe a particular trial or to take notes in court. The court did not formally hold illegal the district judge's refusal to allow Repeta to take research notes-because the judge was merely following the general practice in Japan at the time. However, the Justices did shift policy decisively towards greater respect for freedom of note-taking in court. They characterized the judge's denial of permission to Repeta as "an exercise of the courtroom

105. The United Nations' declaration provides that "[e]veryone has the right to freedom of opinion and expression; this right includes freedom to hold opinions without interference and to seek, receive and impart information and ideas through any media and regardless of frontiers." United Nations Universal Declaration of Human Rights, General Assembly Resolution 217 A(III) of Dec. 10, 1948, art. 19. The International Covenant reads:

1. Everyone shall have the right to hold opinions without interference.

2. Everyone shall have the right to freedom of expression; this right shall include freedom to seek, receive and impart information and ideas of all kinds, regardless of frontiers, either orally, in writing or in print, in the form of art, or through any other media of his choice.

3. The exercise of the rights provided for in paragraph 2 of this article carries with it special duties and responsibilities. It may therefore be subject to certain restrictions, but these shall only be such as are provided by law and are necessary: (a) For respect of the rights or reputations of others; (b) For the protection of national security or of public order (ordre public), or of a public health or morals.

International Covenant on Civil and Political Rights, United Nations General Assembly Resolution $2200 \mathrm{~A}$ (XII) of Dec. 16, 1966 (entered into force on Mar. 26, 1976; ratified by Japan June 1979). The full texts of these and other documents, along with excellent analyses, can be found in D. Forsythe, Human Rights and World Politics (2d ed. 1989).

106. 1222 Hanrei Jihō 28; 1262 Hanrei Jihō 30 .

107. 43 Minshū 89. 
police power poorly grounded in reason," which did not show proper appreciation of the importance of taking notes in court. While the court denied that a legal right to take notes arises from Article 82's open-trial provision, it did recognize that a freedom of courtroom note-taking should be respected in light of Article 21 freedom of expression. The court's language was reminiscent of the affirmation of newsgathering freedom (shuzai nojiyū) in the Hakata decision. ${ }^{108}$

Until this decision, according to a survey of major democracies taken by the Japan Federation of Bar Associations, Japan and South Korea were alone in virtually banning note-taking in court. The other democracies have long taken for granted a freedom to take notes in court. Although the Court's wording gave preferential position to the public importance of news reporters, its recognition that all, citizens and foreigners alike, ${ }^{109}$ have a virtual right to take notes opens the courtroom to scholars, freelance and magazine writers, novelists, and others hitherto denied the right because they did not belong to reporters clubs. For example, novelist Ryuzo Saki filed suit in Tokyo in April 1988 because he was prohibited from taking notes while covering a murder trial for a magazine. ${ }^{110}$ Both the courts and the reporters clubs illustrate the pattern of tension in Japan between democratic openness and self-protective groupism.

It is a paradox that, due to the organized restraints on freedom attendant to the reporters clubs, a free press with such impressive resources should be a symbol of a closed society in an age of burgeoning internationalism. The system deserves to be more widely known. Hundreds of reporters clubs provide the main source of news for Japan's mass media." 11 First organized by reporters in the 1920s to ease liaison with news sources in government and politics, the clubs became government tools for controlling the news during the authoritarian militarist period, from about 1930 until September 1945. With the postwar revolution, the media and their reporters clubs became free and have operated independently under the self-regulatory guidelines of the Publishers Association. Now, each of the major newspapers, news agencies, and radio-television networks assigns one or more reporters to each major reporters club. Reporters clubs, by custom, have their own offices at the government ministries, the Diet, the political party headquarters, the police department, economic organizations, ${ }^{112}$ the courts, the Prime Minister's Office in Tokyo, and at other strategic locations throughout the country.

108. 23 Keishū 1490.

109. "Except for those rights with special characteristics indicating they have only Japanese citizens as their subject, the fundamental human rights guaranteed under Chapter III of the Constitution extend equally to foreigners residing in our country." McLean v. Japan, 32 Minshū 1223 (Sup. Ct., G.B., Oct. 4, 1978), cited in Repeta, 1299 Hanrei Jihō 43-44 as claiming equal rights for foreigners). See also, L. BEER, supra note 11, at 363-64. In the 1980s, progress was made in Japanese statutory law and policy towards equal treatment of foreigners residing in Japan.

110. Yomiuri Daily News, Jan. 26, 1989.

111. L. BeER, supra note 11, at 303; Masaaki, Mass Media in Japan, Japan Foundation (1983); Yamamoto, The Press Clubs of Japan, 15 J. Japanese Stud. 371 (1989).

112. For example, for business, Keidaren; for labor unions, Rengo. 
Reporters clubs meet with representatives of such agencies at least once daily; they also call press conferences. Typically, reporters go from home to the reporters clubs, not to their employers' offices. They file their stories by messenger or electronic means. Over time, many reporters develop close ties with their sources and with their colleagues from competing media companies. Four problems for press freedom in this otherwise excellent and efficient news-producing system may be:

1. In the news-gathering relationships between reporters-who cover one "beat" for only two or three years-and agencies, the reporters may not be a match for the well-briefed government or business "spin artists" who slant the news.

2. Reporters from different media companies do not compete for news, but may rather form a consensus on what should and should not be reported by the club, and may ostracize a reporter who deviates from the shared view (occasioning perhaps a transfer of the reporter rather than vigorous support from his editor's office).

3. Nonmembers, domestic and foreign, are excluded from the main national newsgathering process.

4. The group-dependent context of newsgathering may discourage independent investigative journalism.

Foreign correspondents, even if competent in Japanese and Japan's affairs, have not been admitted to reporters clubs. Nor have they been welcome at reporters clubs' press conferences as nonmembers, with few exceptions. For example, foreign correspondents have been welcome at the Prime Minister's Official Residence Reporters Club since 1965. To ameliorate this restrictive situation, the Publishers Association issued new guidelines in 1985, urging that "[ $\mathrm{t}]$ he press clubs extend cooperation, where possible, for foreign correspondents stationed here with certain accreditation, and give assistance to them, such as allowing them to attend the official press conferences sponsored by the clubs." 113 A Tokyo English-language paper editorialized:

\footnotetext{
Now it is one small step to admit them to press conferences, another to allow them to ask questions there. However, we all know that the most significant news does not come out of these meetings but instead at nonattributable briefings, and for the present at least there is absolutely no thought of ever admitting foreigners to these. ${ }^{114}$
}

For reasons both good and bad, democratic governments are generally more at ease about leaking political secrets to domestic newsmen than to foreigners. The organizational system of the reporters clubs, however, makes news-gathering in Japan more than ordinarily difficult for "outsiders." The assertive groupism and competitive factionalism of the social culture, which encourages free and diverse discourse in many other settings, and which

113. Japan Times Weekly, Sept. 21, 1985.

114. Id. 
characterizes the competition among newspapers for subscribers, does not often extend into news-reporting processes.

\section{IX}

\section{History Textbooks and Nationalism}

The final media-related controversy touched on, the Ienaga textbook review cases, 115 illustrates the impact that nationalism and bureaucratism can have on freedom of expression, in particular on the freedom to write and publish history textbooks for precollege students. Japan's education establishment seems to lack a consensus on how to treat history and "State Shinto"' 16 in the schools and in political discourse. Students learn little about Japan's Second World War history at school, in part because university entrance exam questions focus on earlier history. For about twenty-five years, Saburo Ienaga, a distinguished historian, has struggled in court with the Education Ministry over its tampering with the content of different editions of his high school history text, which takes a critical view of the country's history. Three suits have been filed, in 1965, 1967, and 1984, and a number of district court, high court, and Supreme Court decisions have been handed down, beginning in 1970.117 As the representative of the democratic state, the Ministry emphasizes its own authority and duty to assure accuracy, quality, and balance in precollege texts, as opposed to any rights of parents and educators. Ienaga, like some others, has long worried about a reversion to prewar aggressive nationalism and statist government rooted in Shinto. It may well be that the complicated processes of writing, editing, certifying, publishing, locally selecting, and marketing history textbooks contain unintended restraints on freedom more important than intentional bureaucratic censorship by the Education Ministry. In any case, ideological polarization accentuates the disagreements. ${ }^{18}$ Since school textbooks may convey to young people the most authoritative version of the nation's history they encounter, the issues are worthy of great constitutional controversy.

In court, Professor Ienaga challenged the Ministry's textbook-review criteria and procedures as unconstitutional interference with his freedoms of

115. Ienaga v. Minister of Education, Japan, 604 Hanrei Jihö 35 (Tokyo Dist. Ct., July 17, 1970); Ministry of Education v. Ienaga, 800 Hanrei Jihō 19 (Tokyo H. Ct., Dec. 20, 1975); 1040 Hanrei Jihō 3 (Sup. Ct., lst P.B., Apr. 8, 1982); Ienaga v. Minister of Education, 751 Hanrei Jihō 50 (Tokyo Dist. Ct., July 16, 1976); 1188 Hanrei Jihō 1 (Tokyo H. Ct., Mar. 19, 1986). See also L. BeER, supra note 11, at 254-73; Beer, Japan's Constitutional System and Its Judicial Interpretation in LAW AND SOCIETY IN CONTEMPORARY JAPAN 23-24 (J. Haley ed. 1988).

116. The term "State Shinto" is used here because in the past fifteen years a pattern of judicial decisions and other acts of government may in effect have given uniquely privileged status to Shinto. Shinto is not a religion in the sense of a universal religion or religion as understood in the West. It became infected with statism under the Meiji Constitution, and the trend noted seems more a mode of expressing neonationalism than of uniting religion and the state. See especially Takizawa, Religion and the State in Japan, J. Church \& ST., Winter 1988, at 89; see also L. BeER, supra note 11, at 248-54; H. Hardacre, Shinto and the State, 1868-1988 (1989); Higuchi, When Society Is Itself the Tyrant, 35 JAPAN Q. 350 (1988); Shōchoō Tennōsei, JuRisto (May 5, 1989).

117. See supra note 115.

118. The context is explained in L. BEER, supra note 11, at 252-64. 
thought and expression and his academic freedom, as well as with a child's right to education. ${ }^{119} \mathrm{He}$ also challenged recommended or required changes of content. Under the certification system, a textbook author must submit a manuscript for review by the Ministry's examiners. A certain point total is necessary for approval, and points are taken off for factual errors, lack of balance, and other deficiencies. Even when a manuscript is approved, examiners commonly suggest or require changes in many places. Regarding content, three of the points on which the Ministry and Ienaga sharply disagreed were his text's references to: (1) all of Japan's earliest mythological Shinto writings (subete) as simply a means of legitimizing control of the government by the emperor; (2) workers and farmers as the more important makers of history rather than some better-known historical figures; and (3) the Russo-Japanese Neutrality Pact of the early $1940 \mathrm{~s}$ as a means used to strengthen Japan's position for a strategy of advancing into southern Asia. ${ }^{120}$ The Ministry deleted picture captions referring to ordinary people as "the mainstay of history" and insisted that the reference to the neutrality agreement with the Soviet Union include the phrase "after an overture from the Soviet Union."

The complex judicial decisionmaking since 1970 has resulted in victories and defeats for both sides. The courts have affirmed the author's freedom and the need for great Ministry caution lest examiners tamper improperly with content, while also recognizing the duty and prerogatives of the state as representative of the sovereign people in precollege textbook certification. In some instances, as in the 1982 Supreme Court decision, ${ }^{121}$ judges have avoided most of the great issues by reliance on legal technicalities.

On October 3, 1989, the Tokyo District Court ${ }^{122}$ ruled on Ienaga's 1984 suit against government tampering with his coverage of modern history in the 1980 edition of his text. While awarding compensation for an abuse of authority on one point, the court upheld the Ministry's position on seven other disputed passages, deleting, for example, discussion of wartime experiments on thousands of Chinese by "731 Unit" in Manchuria. In out-ofcourt negotiations, Ienaga seemed more successful. The Ministry yielded on two key points: "Japan's invasion" of China was called an invasion, not an "advance", and the Nanjing Massacre (1937) of "many Chinese civilians and soldiers" was attributed to "the Imperial Japanese Army," not "chaos."

Over the years, politicians and officials on the right have sought change in the content of history textbooks in order to further cloud the mythological, ahistorical nature of very early writings on Japan's origins and the imperial

119. See 1947 Const. arts. $19,23,26$

120. See L. BEER, supra note 11 , at 252-64.

121. 1040 Hanrei Jihō 3; see Sonobe, Dainiji Ienaga Soshō Saikōsaihanketsu no Höri, 770 Jurısuto 2627 (July 1, 1982).

122. Ienaga v. Minister of Education, Japan, Asahi Shinbun (evening edition), Oct. 3, 1989; The Japan Times, Oct. 4, 1989. The 1987 suit was held moot by the Tokyo High Court in 1989 due to changes in the government's curricular guidelines. Minister of Education, Japan v. Ienaga, 1317 Hanrei Jihō 36 (Tokyo H. Ct., June 27, 1989). 
institution, and to gloss over Japan's colonialism in Korea (1905-1945) and wartime aggression against China and Southeast Asian nations. For example, in the 1980s, revised Education Ministry guidelines for history textbook writers drew not only domestic criticism but also expressions of outrage from Asian neighbors at Japan's dishonesty and insensitivity. Bitter conflict arose between the Education Ministry, which insisted on national sovereignty in textbook matters, and the Foreign Ministry, which is responsible for maintaining good neighborly relations.

More typical of her relations with other Asian nations since 1945, Japanese officials have given war reparations, aid, investment, and trade, and have expressed regret, sorrow, and/or apology to Asian countries for the Second World War. But as Japan rose in the world's power hierarchy in the 1980s, some public figures-notably in relation to the textbook controversy-showed confidence bordering on national arrogance. Unabashed state support of Shinto increased, and "foot-in-mouth disease" spread. In a rare and extreme incident, Kamai Shizuka, a conservative member of parliament, warned critical representatives of Korea that continued interference with Japan's internal textbook affairs could eventually lead to war. ${ }^{123}$ For the indefinite future, Asian nations will remain acutely sensitive to how openly and straightforwardly textbooks and officials treat Japan's behavior during the Pacific War. The persisting concern of Ienaga and others about the implications of nationalism and restrictive bureaucratism for freedom of expression and other rights will remain timely.

\section{$\mathrm{X}$}

\section{Conclusion: Freedom and Community in Constitutional Cultures}

Each constitutional democracy is a partially open, partially closed, coherent cultural whole, operating according to a sometimes subliminal consensus about what should be done for survival, success, and adherence to national values. Each constitutional culture nurtures, protects, regulates, and represses freedom of expression in ways often determined more by its own rules and customs than by law, government institution, or abstract ideal. Freedom lives or dies in the interplay between the public and private sectors. A relevant conviction-for example, a consensus that each person has inherent and equal dignity under God,or Nature-may improve the status of free speech in competitive politics, defined as the degree to which ordinary people in a polity may peacefully express themselves on any subject with

123. Japan Times, Oct. 31, 1986, at 3, col. 3. These were hardly representative words from a nation with an impeccably peaceful record in international relations since 1945 . Yet, as citizens of Germany, the United States, and other countries well know, facing national mistakes and tragedies of the past squarely and consistently is too painful for many to bear, even when it is essential for grappling with present problems. For an incident involving Japan's role in World War II, see Oka, Outspoken Minister Tests Leadership of Japan's Takeshita, Christian Sci. Monitor, May 16, 1988, at 12, col. 1; Sneider, History Controversy Again Stirs Japan, Christian Sci. Monitor, May 11, 1988, at 9, col. 1. 
impunity. But the impact on actual practice of such a national principle can be exaggerated or misconstrued.124 For example, a nonindividualist groupism is as compatible or more compatible with freedom of expression in sociolegal practice than are some types of individualism.

What is often called "Western individualism" in American discourse on rights and their foundations is a cluster of attitudes peculiar to the United States, not a characteristic of the Western world or of constitutional democracies in general. ${ }^{125}$ In some respects, these attitudes are incompatible with the conception of human rights in human rights documents of the United Nations and other international agencies. ${ }^{126}$ For example, a rather extreme emphasis in America on economic liberty and on the human as a free chooser apart from his or her community context does not seem to fit easily with respect for the rights of others implied by their equal human dignity. On the other hand, as Robert Bellah and others show, the "individualism" of the United States is not univocal, but diverse and complex in meaning; so generalizations here admittedly would need qualification. ${ }^{127}$ In some forms, the cultural imperative of U.S. individualism weakens rather than buttresses the status of rights and freedom; in other contexts, probably less common than Americans tend to think, individualism adds sociopolitical strength to freedom of expression. Analogously, under Japan's written and unwritten constitutions, groupism operates both for and against free speech, depending on the people and context involved. In general, groupism may provide a stronger basis in the social structure for a vigorous system of freedom of expression under law than some forms of individualism, because "an individual outside a group is ineffectual and generally much less competent than a well-organized group in preserving, developing, and expressing an

124. K. Greenawalt, Speech, Crime, and the Uses of Language (1989) (fusion of such theory with detailed analysis of context and empirical data seems the necessarily laborious way of gaining wisdom when assessing a nation's free-speech record). Greenawalt, Free Speech Justifications, 89 Colum. L. Rev. 119 (1989) (free-speech theory that includes attention to the significance of urging, requesting, encouraging, threatening, and other communicative acts which vary importantly in manner with culture).

125. McKay, Why Is There a European Political Science?, 21 Pol. Scr. \& Pol. $1051-54$ (1988). The relatively narrow "liberal individualism" (of the left, the right and the center) underlying American social science contrasts sharply with the diversity of intellectual and political views in Europe, reflecting perhaps the narrow spectrum of political parties that the constitutional culture of the United States finds tolerable.

126. Legal positivism and economic liberalism seem to militate against establishment in American law and policy of socioeconomic rights taken for granted in many constitutional democracies, and to weaken attention to equality of criminal justice rights. Regarding socioeconomic rights, see International Covenant on Economic, Social and Cultural Rights, United Nations General Assembly Resolution, 2200A(xxi) of Dec. 16, 1966, which, with the Universal Declaration of Human Rights, supra note 105, and the International Covenant on Civil and Political Rights, supra note 105, is referred to as the "International Bill of Rights." On U.S. and international rights, see J. Auerbach, Unequal Justice: Lawyers and Social Change in Modern America (1976); P. Sighart, The Lawful Rights of Mankind: An Introduction to the International Legal Code of Human Rights (1985); Human Rights Sourcebook (A. Blaustein ed. 1987); International Human Rights InStruments of the United Nations, 1948-1982 (UNIFO ed. 1983).

127. See R. Bellah, R. Madsen, W. Sullivan, A. Swindler, \& S. Tipton, Habits of the Heart: Individualism AND Commitment in AMERICAN Life (1985). 
idea for consideration by relevant publics."128 Yet inward-looking groupism may exacerbate the problems of restrictive bureaucratism in Japan's government and myopic pursuit of group interests by some private groups.

In Japan's democratic politics and law since 1945, however, coherent groups have formed and have vigorously, freely, and peacefully pursued their ends. In comparative terms, it is not freedom itself that is usually pursued by activists in democracies-as in Burma and South Korea in 1988, in China in 1989 , or in the Philippines earlier-but some concrete benefit or change of policy. ${ }^{129}$ Japan's mass media will continue to regulate themselves and effectively protect their own prerogatives. The Japanese courts are likely to continue protection of press freedom, and they may become more at ease in the future about collective activities than they have been in decisions discussed here. In any case, irrepressible group actions involving workers, media companies, students, Burakumin, ${ }^{130}$ housewives, farmers, and other components of society seem as perennially essential to the nation's constitutional democracy as periodic elections and restraints on government power under law.

The study of democratic constitutionalism in radically different cultures makes more obvious to the student the difficulty of clearly separating the public and private sectors, and of formulating theory or assessing national performance in such a way as to separate appropriately what is essential from what is peculiar to a particular country or group of nations. Identification of the distinctive specific helps and obstacles to free speech found within any given constitutional culture can provide a foundation for taking remedial steps in law, administration, and the private sector. ${ }^{131}$

Theory regarding freedom of expression and constitutionalism awaits adequate attention to groupism and a more careful sorting out of the different meanings of individualism for its future development. As a transculturally neutral term that may better express the ideal and empirical nature of freedom in a constitutionalist community, I would offer the encapsulating word "mutualism." "Mutualism" integrates both the individual and the social sides of freedom and other rights more organically than either "individualism" or "groupism." "Mutualism" points to the inherently reciprocal nature of individual rights, the mutual regard and respect they

128. L. BEER, supra note 11 , at 398 .

129. See W. SPINRAd, Civil Liberties (1970), and the synopsis of his sociology of free speech in L. BEER, supra note 11, at 403-04.

130. Burakumin are descendants of persons classified as nonhuman, or not belonging to human society, during the Tokugawa period (approximately 1600 to 1868). Although all legal classifications of Burakumin were eliminated shortly after the Meiji restoration, social discrimination continues. See F. Upham, Law and Social Change in Postwar Japan 78 (1987).

131. Examples of remedial constitutionalism are the provisions in the 1987 Constrtution OF THE PhILIPPINEs against appointing relatives to government office, in reaction against the nepotism of the past. The Constitutions of both the Philippines and South Korea limit presidents to one term in office (six years and five years respectively), to counter the tendency of leaders in those countries to perpe iuate themselves in power. Article 9 of the Japanese Constitution may also be seen in this light as a remedy for extreme militarization of government and politics before the end of World War II. 
demand, and their existence within concrete interpersonal relationships of specific communities, not in individualist isolation, in an imaginary universalist world, or in groupist submersion. "Mutualism" also offers a perspective which is compatible with the powerful affirmation of human dignity at the foundation of Japan's constitutional democracy and human rights. ${ }^{192}$

132. The primary governmental purpose of freedom of expression does not seem to be to assure through debate and voting the determination and implementation of the majority will on any subject ("democracy"), but rather to assure the persistent pursuit of fundamental human rights for all citizens and to regularize limitations on government power ("constitutional democracy"). The dilemma is not between majority rule and minority rights, whether the minority be privileged or severely deprived. Instead, the problem is adding to the notions of majority rule and majority rights those of equal protection and promotion of the basic human rights of all. Human rights do not reside in the individual apart from others; rather, they are enjoyed or violated within interpersonal relationships, whether the right in question is to food or to reputation. 
